University of Nebraska - Lincoln

DigitalCommons@University of Nebraska - Lincoln

Faculty Publications from the Harold W. Manter Laboratory of Parasitology

6-1964

\title{
Studies on the Helminth Fauna of Alaska. XL. Strigea gruis sp. n., a Trematode Parasite of Grus canadensis (L.)
}

Georges Dubois

Corcelles (Neuchâtel)

Robert L. Rausch

University of Washington, rausch@uw.edu

Follow this and additional works at: https://digitalcommons.unl.edu/parasitologyfacpubs

Part of the Parasitology Commons

Dubois, Georges and Rausch, Robert L., "Studies on the Helminth Fauna of Alaska. XL. Strigea gruis sp. n., a Trematode Parasite of Grus canadensis (L.)" (1964). Faculty Publications from the Harold W. Manter Laboratory of Parasitology. 375.

https://digitalcommons.unl.edu/parasitologyfacpubs/375

This Article is brought to you for free and open access by the Parasitology, Harold W. Manter Laboratory of at DigitalCommons@University of Nebraska - Lincoln. It has been accepted for inclusion in Faculty Publications from the Harold W. Manter Laboratory of Parasitology by an authorized administrator of DigitalCommons@University of Nebraska - Lincoln. 


\title{
Studies on the Helminth Fauna of Alaska. $\mathrm{XL}$. Strigea gruis sp. $\mathrm{n}$, a Trematode Parasite of Grus canadensis (L.)
}

\author{
Georges Dubois and Robert L. Rausch \\ Corcelles (Neuchâtel), Switzerland, and Arctic Health Research Center, Public Health \\ Service, U. S. Department of Health, Education, and Welfare, Anchorage, Alaska
}

\begin{abstract}
Strigea gruis sp. n. (Trematoda : Strigeata, Strigeidae) is described from the sandhill crane Grus c. canadensis (L.). Only one other species of Strigea (S. neotidis Bisseru, 1956) is known from birds of the order Gruiformes; it is distinguished from S. gruis by several characteristics including its slender form, campanulate anterior segment, size of pharynx and of eggs, position of ovary, and position and size of testes. S. gruis differs from two other species having a relatively large pharynx, S. sphaerula (Rudolphi, 1803) and S. intermedia Szidat, 1932, both parasites of corvids, in the form of the anterior segment and in details of the genital organs.
\end{abstract}

During the period 1955 to 1963,13 specimens of sandhill crane, Grus c. canadensis (Linnaeus), were collected in Alaska by personnel of the Zoonotic Disease Section, Arctic Health Research Center, and examined for helminths. An undescribed species of trematode belonging to the family Strigeidae Railliet, 1919, of the suborder Strigeata La Rue, 1926, was found in three birds.

The infected hosts were collected as follows: (No. 24638) 15 July 1960 at Goose Bay, Cook Inlet; (No. 26336: type material) 18 May 1961 at Potter Marsh, about 10 miles south of Anchorage; (No. 29436) 16 June 1963 at Potter Marsh. The birds, all adults, had 7, 80, and 5 of these strigeids, respectively.

\section{Strigea gruis sp. $n$.}

(Figs. 1 and 2)

(All measurements in millimeters)

\section{Diagnosis}

Length of body 1.44 to 2.32 (avg 2.01). Anterior segment globular or subglobular, measuring 0.56 to 0.82 (avg 0.69) in length. Posterior segment sacciform or, when contracted, reniform, usually twice as long as anterior segment, measuring 0.88 to 1.59 (avg 1.33) in length. Reniform ovary, measuring 0.115 to 0.230 by 0.160 to 0.340 , situated in first fifth of posterior segment. Last fifth of posterior segment containing copulatory bursa; latter more or less delimited dorsally and provided

Received for publication 5 December 1963. with muscular ring ("Ringnapf"), measuring 0.170 to 0.270 in depth. Remainder of posterior segment occupied by large, lobulated testes, anterior testis measuring 0.200 to 0.420 by 0.290 to 0.580 and posterior testis, 0.225 to 0.480 by 0.300 to 0.580 . Voluminous seminal vesicle situated between lobes of posterior testis. Proteolytic gland, subequal to size of ovary, measuring 0.105 to 0.200 by 0.145 to 0.245 . Terminal buccal sucker measuring 0.115 to 0.180 by 0.115 to 0.210 ; spherical pharynx, 0.105 to 0.160 by 0.100 to 0.160 , nearly equaling latter in size. Ventral sucker, measuring 0.160 to 0.250 by 0.135 to 0.235 , masked by vitellaria, latter extending anteriad to level of pharynx and in posterior segment reaching ventrally as far as mid-length of largely exposed copulatory bursa, with concentration at margin of ceca. Vitelline reservoir and Mehlis' gland intertesticular. Laurer's canal present. Ductus ejaculatorius opening into uterus shortly after entrance of latter into base of genital cone. Eggs, numbering from 1 to 35, average 0.103 by 0.65 .

Comparative measurements of individuals from three hosts are presented in Table I.

Host: Grus c. canadensis (Linnaeus).

Habitat: Small intestine.

Type locality: Potter Marsh, about 10 miles south of Anchorage, Alaska.

Type: In the collection of the senior author, Zoological Institute, University of Neuchâtel.

Paratypes: USNM Helm. Coll. No. 59003.

\section{DISCUSSION}

Strigea gruis sp. $\mathrm{n}$. is characterized by its globular anterior segment and by the comparatively large size of the pharynx, by the extremely anterior position of the ovary in the 

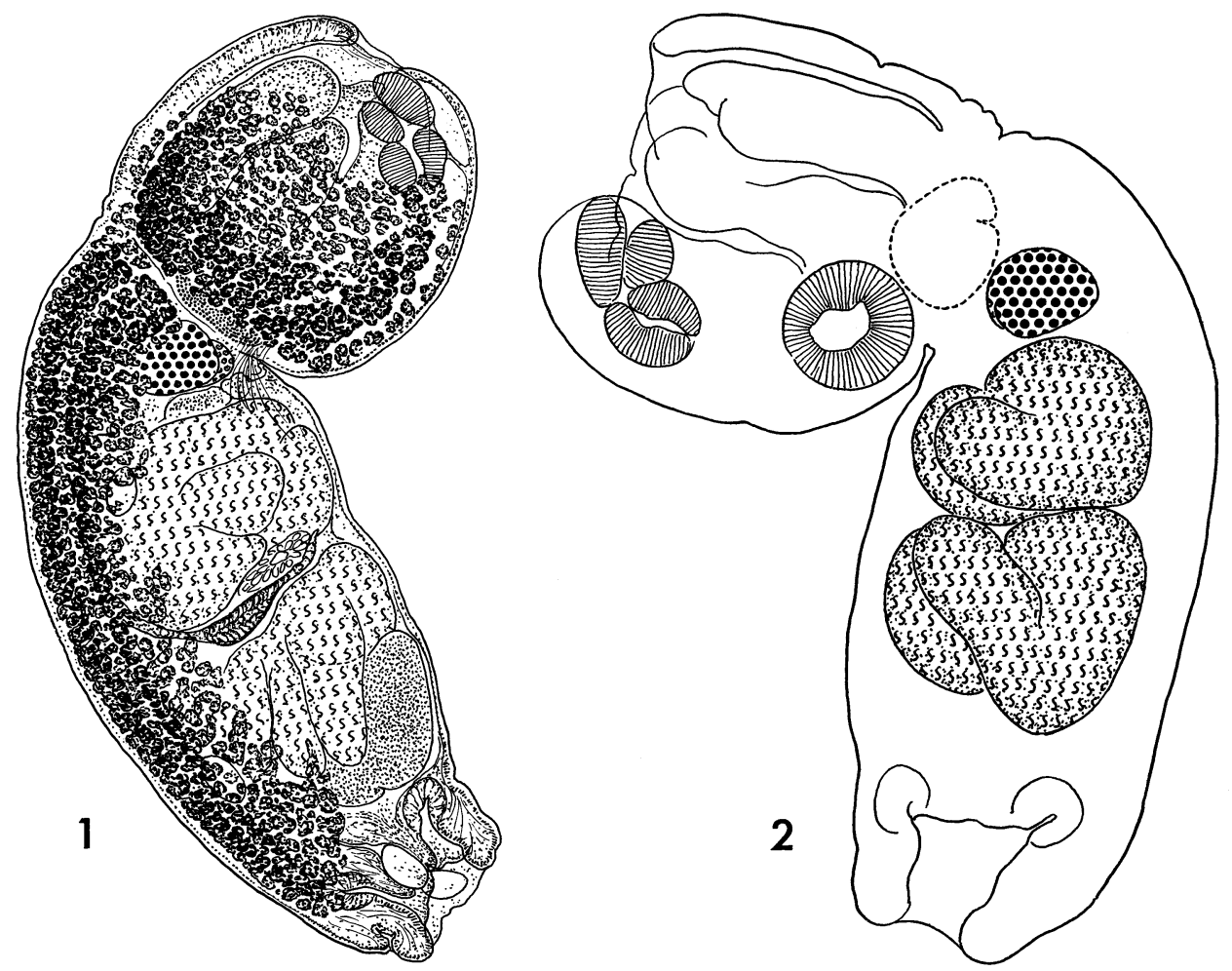

Figures 1 AND 2. Strigea gruis sp. n. from Grus canadensis. 1. From host No. 26336. Length $2.22 \mathrm{~mm}$. 2. From host No. 29436. Topographic scheme of the genital glands. Length $1.78 \mathrm{~mm}$.

TABLE I. Dimensions of Strigea gruis sp. n. (in millimeters).

\begin{tabular}{|c|c|c|c|}
\hline & No. 26336 & No. $24638^{1}$ & No. 29436 \\
\hline Total length & $1.71-2.32$ & $1.44-1.67$ & 1.78 \\
\hline $\begin{array}{l}\text { Anterior segment: } \\
\text { Length } \\
\text { Width }\end{array}$ & $\begin{array}{l}0.62-0.82 \\
0.66-0.86\end{array}$ & $\begin{array}{l}0.56-0.69 \\
0.53-0.58\end{array}$ & $\begin{array}{l}0.63 \\
0.66\end{array}$ \\
\hline $\begin{array}{l}\text { Posterior segment: } \\
\text { Length } \\
\text { Width }\end{array}$ & $\begin{array}{l}1.07-1.59 \\
0.61-0.80\end{array}$ & $\begin{array}{l}0.88-1.00 \\
0.47-0.52\end{array}$ & $\begin{array}{l}1.19 \\
0.54\end{array}$ \\
\hline Buccal sucker & $0.140-0.180 \times 0.135-0.210$ & $0.115-0.157 \times 0.115-0.135$ & $0.165 \times 0.140$ \\
\hline Pharynx & $0.130-0.160 \times 0.130-0.160$ & $0.105-0.130 \times 0.100-0.125$ & $0.135 \times 0.135$ \\
\hline Ventral sucker & $\begin{array}{l}0.170-0.250 \times 0.160-0.235 \\
\quad \text { or } 0.200-0.220\end{array}$ & $0.160-0.190 \times 0.135-0.167$ & $0.200-0.210 \times 0.170-0.210$ \\
\hline Ovary & $0.170-0.230 \times 0.230-0.340$ & $0.115-0.135 \times 0.170-0.190$ & $0.135-0.160 \times 0.160-0.180$ \\
\hline Anterior testis & $0.340-0.420 \times 0.470-0.580$ & $0.200-0.225 \times 0.290-0.300$ & $0.330-0.370 \times 0.360-0.370$ \\
\hline Posterior testis & $0.300-0.480 \times 0.470-0.580$ & $0.225-0.270 \times 0.300-0.310$ & $0.360-0.370 \times 0.370-0.410$ \\
\hline Eggs & $\begin{array}{c}0.90-0.115 \times 0.60-0.68 \\
\quad(\text { avg } 0.104 \times 0.65)\end{array}$ & $0.94-0.100 \times 0.70$ & - \\
\hline Proteolytic gland & $0.170 \times 0.245$ & $0.105 \times 0.145-0.190$ & $0.160-0.200 \times 0.230-0.240$ \\
\hline $\begin{array}{l}\text { Extent of the } \\
\text { copulatory bursa }\end{array}$ & $0.170-0.270$ & $0.190-0.210$ & 0.190 \\
\hline $\begin{array}{l}\text { Location of ovary } \\
\text { proportional to } \\
\text { length of pos- } \\
\text { terior segment }\end{array}$ & $\begin{array}{c}8-20 / 100 \\
(\operatorname{avg} 12 / 100)\end{array}$ & & $\begin{array}{c}9-12 / 100 \\
(\operatorname{avg} 11 / 100)\end{array}$ \\
\hline
\end{tabular}

${ }^{1}$ Includes some specimens in the early stage of sexual maturity (two eggs in the uterus). 
posterior segment, and by the great development of the testes and seminal vesicle.

A single species of Strige a has been recorded as a parasite of birds of the order Gruiformes: Strigea neotidis Bisseru, 1956, from Neotis cafra denhami (Children) [Otidae], from Northern Rhodesia (Bisseru, 1956). This African species differs from $S$. gruis by its narrower posterior segment, its cupuliform to campanulate anterior segment, the small size of the pharynx ( 0.079 by $0.058 \mathrm{~mm})$, the position of the ovary almost at the middle of the posterior segment (ratio 38 to $44 / 100$ ), by the weakly developed testes situated in the third quarter of the segment, and by the larger size of the eggs $(0.115$ to 0.130 by 0.061 to $0.068 \mathrm{~mm}$ ).

Strigea gruis may be compared with only two additional species, S. sphaerula (Rudolphi, 1803) and S. intermedia Szidat, 1932, both of which have a relatively large pharynx (Szidat, 1932; Dubois, 1938). These trematodes, both parasites of corvids, differ distinctly from $S$. gruis in having a hemispheric or cupuliform, depressed anterior segment, with a very large opening. S. sphaerula also possesses well-developed, massive, or slightly lobed testes, with the ovary situated well anterior in the posterior segment ( 10 to $24 / 100$ ), but this species has a small seminal vesicle.

\section{LITERATURE CITED}

Bisseru, B. 1956. On four new trematodes of the genus Strigea from Central African birds of prey. J. Helm. 30: 63-79.

Duвois, G. 1938. Monographie des Strigeida (Trematoda). Mém. Soc. Neuchâtel. Sci. Nat. 6: 1-535.

Szidat, L. 1932. Parasiten aus Liberia und Französisch-Guinea. II. Teil: Trematoden. Ztschr. Parasitenk. 4: 506-521. 